\title{
The Impact of Multi-Sensory Phonics Programs in Teaching English as an Additional Language
}

James Langille

Werklund School of Education, University of Calgary

Zoila Green

Werklund School of Education, University of Calgary

\begin{abstract}
Complexity of the various needs that come with English language learners (ELLs) beyond language learning (such as learning gaps, social and cultural differences, etc.) and increased numbers of English language learners in Canadian schools have led educational stakeholders to seek ways to promote reading improvement. While literature points out the relevance of systematic phonics instruction in reading and the importance of form-focused instruction (FFI) in English language learning, multi-sensory phonics programs (MSPPs) appear to be an effective reading tool that embodies them both. Although evidence on the efficacy of these programs is copious in students with learning difficulties, little is known about MSPPs in connection with English language learning. As a result, this integrative literature review
\end{abstract}


explores the notable benefits of MSPPs, their connection with ELL instruction, and how successful program implementation may depend on teacher training.

Keywords: ESL reading, form focused instruction, multi-sensory phonics programs, phonics, phonics instruction, reading difficulties, TEAL

\section{Résumé}

La complexité et l'augmentation du nombre d'apprenants de l'anglais (ELL) dans les écoles canadiennes ont conduit les acteurs de l'éducation à chercher des moyens de promouvoir l'amélioration de la lecture. Alors que la littérature souligne la pertinence de l'enseignement systématique de la phonétique en lecture et l'importance de l'enseignement centré sur la forme (form-focused instruction [FFI]) dans l'apprentissage de l'anglais, les programmes phonologiques multisensoriels (multi-sensory phonics programs [MSPP]) semblent un outil de lecture efficace qui conjugue ces deux éléments. Bien que les preuves de l'efficacité de ces programmes soient nombreuses chez les apprenants ayant des difficultés d'apprentissage, on sait peu de choses sur les MSPP en rapport avec l'apprentissage de la langue anglaise. Par conséquent, cette recension des écrits intégrative explore les avantages notables des $M S P P$, leur lien avec l'enseignement de la langue anglaise et la façon dont la réussite de la mise en œuvre du programme peut dépendre de la formation des enseignants. Mots-clés : lecture ESL, enseignement centré sur la forme, programmes phonologiques multisensoriels, phonétique, enseignement de la phonétique, difficultés en lecture, TEAL 


\section{List of Abbreviations}

$\begin{array}{ll}\text { Abbreviation } & \text { Term } \\ \text { ELL } & \text { English language learner } \\ \text { FFI } & \text { form-focused instruction } \\ \text { FonF } & \text { focus-on-form } \\ \text { focus-on-forms } \\ \text { FonFs } & \text { first language } \\ \text { L1 } & \text { second language } \\ \text { L2 } & \text { learning disabilities } \\ \text { LD } & \text { multi-sensory structured language } \\ \text { MSL } & \text { multi-sensory phonics instruction } \\ \text { MSPI } & \text { multi-sensory phonics programs } \\ \text { MSPPs } & \text { National Institute of Child Health and Human Development } \\ \text { NICHD } & \text { National Reading Panel } \\ \text { NRP } & \text { Orton-Gillingham } \\ \text { OG } & \text { phonemic awareness } \\ \text { PA } & \text { self-efficacy of linguistic knowledge factor } \\ \text { SELF } & \text { self-efficacy of reading factor } \\ \text { SERF } & \text { teaching English as an additional language } \\ \text { TEAL } & \end{array}$




\section{Introduction}

The Report of the National Reading Panel issued by the National Institute of Child Health and Human Development (NICHD, 2000) affirms that phonemic awareness (PA), phonics, vocabulary, fluency, and reading comprehension comprise the foundation of reading development. The report asserts that systematic phonics instruction is more beneficial to reading development when compared to unsystematic phonics or no phonics instruction (pp. 2-89). Especially interesting, multi-sensory phonics programs (MSPPs) not only incorporate the use of systematic phonics, but also use a multi-sensory approach. This makes MSPPs a powerful reading tool with studies pointing out their effectiveness in reading improvement (e.g., Schlesinger \& Gray, 2017).

Evidence supporting the use of multi-sensory phonics programs among struggling readers notwithstanding, the only attempted research in connection to English language learners' (ELLs) reading development encountered in our literature search was that of Schneider and Kulmhofer (2016). The authors assert that a balanced approach to foreign and second language (L2) instruction with integration of multi-sensory structured language instruction provides ELLs, particularly struggling readers, with a realistic chance to succeed. Consequently, the main purpose of this article is to bring forth the review and analysis of existing literature on multi-sensory phonics programs with the objective of determining the impact such programs may have on teaching English as an additional language.

In addition, more recent research (Ellis, 2015; Kellem \& Halvorsen, 2018) argues for the importance of form-focused instruction (FFI) in the promotion of language learning in both its isolated and integrated forms. FFI, by drawing ELLs' attention to the language forms, aids them in noticing language features that otherwise would not be perceived through mere exposure to the language in a Communicative Language Teaching approach. Thus, based on preliminary research and experience with the use of multi-sensory phonics programs as FFI, we believe MSPPs may provide ELLs with a good literacy foundation. With classrooms across Canada becoming increasingly more diverse with a growing presence of ELLs, the goal of education jurisdictions (e.g., Alberta Education, 2009 ) is to support ELLs in developing reading comprehension skills and becoming successful readers. As classroom and language teachers work to support English language 
learners and their reading development, this integrative review reveals how MSPPs, as part of a balanced literacy approach, advance the development of reading skills.

\section{Theoretical Concepts}

\section{Phonics Instruction}

Languages considered to be phonetic possess a phonemic orthography, signifying a correlation between phonemes (letter sounds) and graphemes (letter symbols). However, English is a non-phonetic language as it does not follow a consistent phoneme-grapheme correlation, which requires learners to work on the development of PA and phonics skills by exploring the linguistic aspects of the language. While PA teaches recognition of letter sounds, and the sounds letters make when blended into words, phonics instruction focuses on helping students learn how to link phonemes and graphemes and their patterns in the reading process. Thus, PA and phonics instruction are two separate, yet complementary, processes in learning to read.

With reference to reading, there have historically been different approaches to its instruction, moving from holistic, to meaning-centred, to phonics approaches (NICHD, 2000, pp. 2-9). Nevertheless, based on studies such as the systematic review performed by the National Reading Panel (NRP), findings conclude that systematic phonics instruction provides a higher level of reading achievement in children when contrasted with the achievement levels obtained by use of alternative programs that include unsystematic or no phonics instruction (pp. 2-92). To make clear, it is understood by systematic phonics instruction that organized and methodological phonic sets are explicitly and systematically taught (pp. 2-94). Furthermore, the report of the NRP posits that vocabulary, fluency, reading comprehension, phonemic awareness, and phonics formulate the five core areas of reading instruction (NICHD, 2000).

\section{Multi-Sensory Phonics Programs}

Reading is a fundamental skill that is typically first developed in the early school years and moves toward building depth and complexity in later grades. The early stages of 
reading development are foundational to subsequent school years as students shift from learning to read to reading to learn, which is characterized by moving from reading basic words and texts to reading complex texts to access new knowledge (Pavlov, 2015, p. 31). Consequently, the systematic learning of letters, letter sounds, and blending and decoding of letter-sounds all form the underpinnings of multi-sensory phonics instruction. Moreover, MSPPs teach these components with visual, auditory, tactile, and kinesthetic approaches. Although initially thought to favour students in earlier grades, it is known to have been successfully used with older students, as cited by multiple studies in Warnick and Caldarella (2016).

Multi-sensory phonics instruction facilitates the remediation of reading skills in diverse learners who exhibit significant challenges in reading when compared to those learners who did not receive multi-sensory phonics interventions (Warnick \& Caldarella, 2016, p. 327). Similarly, an earlier study (Stewart, 2011) asserts that the Orton-Gillingham (OG) variants, as MSPPs are also referred to, are effective because of the incorporation of eyes, ears, hands, and voice into manipulating and learning PA, letter-sound correspondence, syllable composition, morphology, syntax, and semantics (pp. 2-3). This approach aligns with different student learning styles, making it engaging and supportive of students' learning preferences. Numerous studies document these benefits and report on their effectiveness in reading improvement in learners with reading difficulties (Campbell et al., 2008; Joshi et al., 2002; Oakland et al., 1998; Scheffel et al., 2008; Schlesinger \& Gray, 2017; Turner, 2008; Warnick \& Caldarella, 2016; Williams, 2008).

\section{English Language Learning}

Early research by McLaughlin (1992) points to the importance of teachers knowing how children learn a second language, asserting that intuitive assumptions and mistakes are too often widely made. In turn, learning could be affected by their teachers because of the unrealistic expectations and inaccurate understandings they embody around the process of second language (L2) learning and its connections with acquiring other academic skills and knowledge (p. 1). As McLaughlin (1992) specifies, many ELLs come to school with linguistically diverse, cognitive, and social norms that often differ from those that govern the mainstream classroom. In order to provide effective programming instruction for 
these students, it is important that teachers adopt an awareness of culturally and linguistically diverse learning styles and differences in the way ELLs learn.

More recently, Svalberg (2007) highlights ways teachers can better understand and enhance their own language development, including English language teaching and learning processes. Svalberg (2007) asserts that explicit teaching is vital for English language learning (p. 290). Likewise, Spada and Lightbrown (2010) point out that effective instruction can impact L2 acquisition. To ensure that the developmental path of English language learners is not altered, Spada and Lightbrown (2010) posit that learners could be provided with natural input through communicative and content-based language teaching where emphasis is on meaning or themes. In doing so, an environment is created whereby learners can develop more effective comprehension and communication skills than the ones typical of traditional language teaching approaches. Moreover, learners within these classroom environments will see greater benefit in language development from more opportunities to focus on language form when instructional input and/or corrective feedback is explicit (Spada \& Lightbrown, 2010, p. 120).

\section{Form-Focused Instruction}

Form-focused instruction constitutes two reciprocal approaches described by Long (1991, as cited in Ellis et al., 2002), focus-on-forms (FonFs) and focus-on-form (FonF) (Ellis et al., 2002, p. 420). The intention of FonFs (isolated FFI) is teaching grammar by following the organization of a structural syllabus through the presentation of linguistic features, providing opportunities for practice and production activities. In contrast, FonF (integrated FFI), seeks to draw student attention to linguistic features that incidentally arise during a lesson with meaning or communication foci (Ellis, 2015, pp. 1-2). Moreover, Ellis (2015) specifies the existence of criterial features that are pertinent to each aspect of FFI. FonFs involves the preselection of a linguistic form and teacher and student awareness on the linguistic target and its practice; while the criterial features of FonF describe it as: observable, incidental, occurring in meaning-centred learning, and transitory (p. 2).

Form-focused instruction, in its isolated and integrated forms, supports ELL instruction as it aids in identifying language features that may not be evident and easily accessible by simple exposure to language in communicative language teaching. Being that phonics-based instruction is a foundational element in Grades K-3, MSPPs, with a 
systematic teaching approach, can support the development of reading skills as put forward in current literature (see, for example, Lai et al., 2014; Warnick \& Caldarella, 2016; Rasinski et al., 2017). These phonics programs, a form of FFI, may provide ELLs, particularly those in grades $\mathrm{K}-3$, with opportunities to manipulate phonemes and to notice phonics features, giving much-needed practice for oral and written production activities.

By recognizing the importance of PA and phonics instruction in reading, and FFI in second language acquisition, this integrative literature review attempts to evaluate studies that have previously examined the use of MSPPs and provide evidence on how these programs could be of value in teaching English as an additional language (TEAL). Based on a synthesis of the articles examined, these questions will be addressed in this review:

1. How are multi-sensory phonics programs beneficial to student learning?

2. How could multi-sensory phonics programs impact teaching English as an additional language?

3. How can teacher training in multi-sensory phonics programs support teacher efficacy?

\section{Methodology}

Multiple studies show the benefits of MSPPs for students with reading challenges and those with learning disabilities (LD) when used as part of a balanced reading program (Campbell et al., 2008; Oakland et al., 1998; Scheffel et al., 2008; Schlesinger \& Gray, 2017; Warnick et al., 2016). This study explores and evaluates differing perspectives on multi-sensory phonics programs, with a critical analysis present throughout all phases of the inquiry. The attempt of this review is to provide evidence on how MSPPs, as a framework for reading skills development, are beneficial in teaching contexts where English as additional language is the focus.

Within the scope of our literature review, informal channels were used, including research findings and personal research from graduate courses. Primary channels used in the study were accessed through online databases and educational journals. In addition, supplementary references supporting the integrative literature review were encompassed in the category of secondary channels. Strategies for validity enhancement included Copper's (1998, as cited in Russell, 2005) data collection strategy, establishing review criteria, and 
including a summary of study demographics, as suggested by Russell (2005), in the form of a literature review chart. The chart displays all the studies included in the review with main features such as research intervention, method, results, limitations, and suggestions.

\section{Methods}

Adopting an integrative review method accounts for the channels selected as data sources. Initially, we sought to find peer-reviewed experimental studies to identify how MSPPs influenced reading skill development in comparison to control groups. It was expected that initial literature for the study would have meaningful sample sizes of at least five participants in the treatment group, with a publication date no earlier than 1998. However, after examining more than 1,500 online full-text articles, the search criteria were expanded (see Figure 1) due to the limited number of articles that were identified as relevant under the original search terms. Other variables included English-language articles only, no participant age restriction, and studies with multi-sensory phonics instruction treatments of English as L1 or L2.

\section{Figure 1}

\section{Literature Search Map}

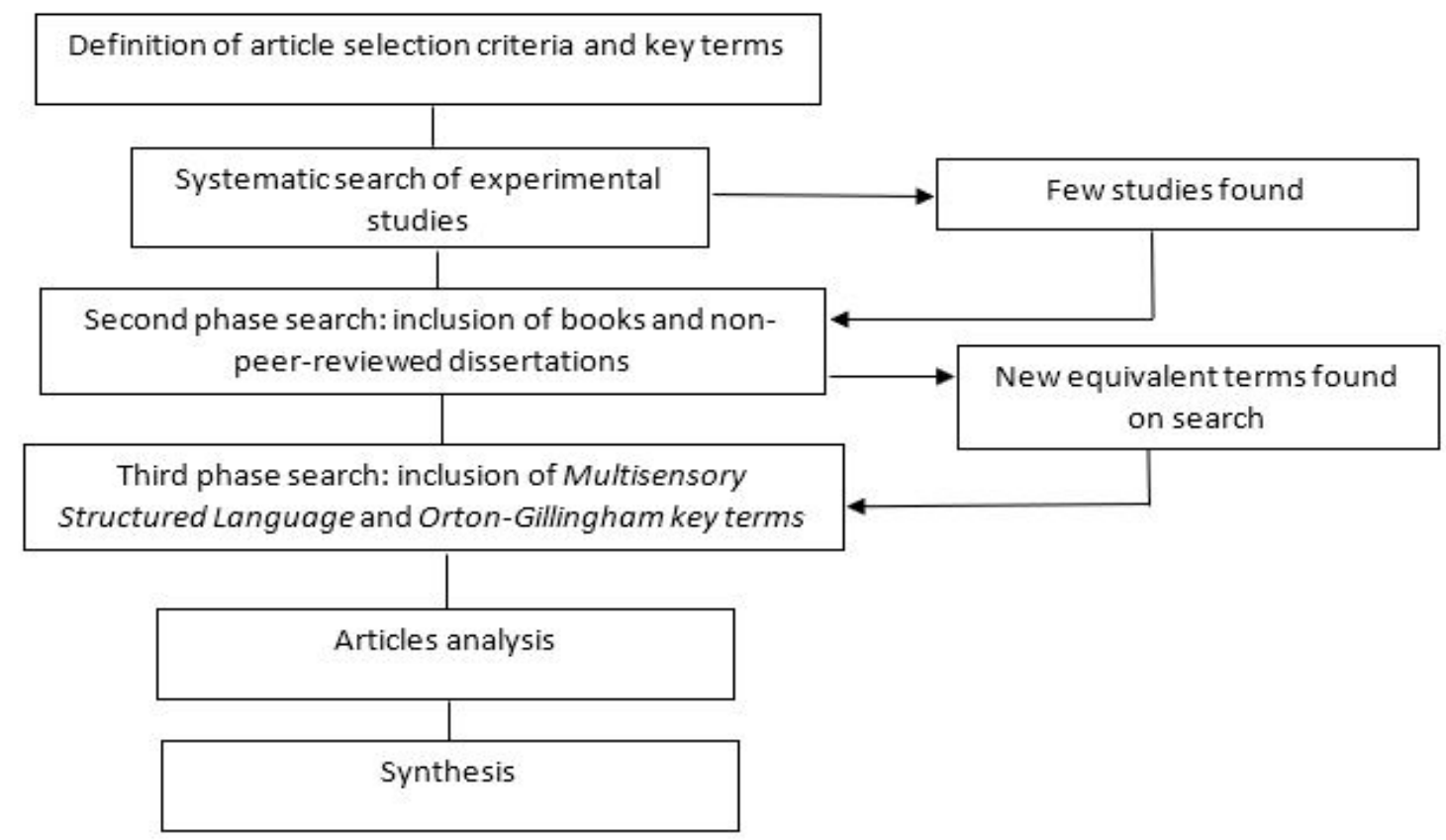


Specific keywords were chosen to streamline and filter articles. Keywords in the integrative literature review included: MSPP, MSPP Instruction, Multisensory Phonics Instruction, Multisensory Phonics, Multisensory Phonics Programs, with $+E S L,+E n-$ glish language learners, and multisensory teaching. Additionally, after further search refinement, Multisensory Structured Language and Orton-Gillingham were included, as they too align with multi-sensory phonics instruction. The search was completed using the University of Calgary database, ProQuest, JURN, ERIC, and Sage Journals. Further parameters were added to the search terms to include contemporary non-peer-reviewed dissertations and a systematic review article.

\section{Analysis}

We reviewed, refined, and adjusted search parameters to ensure articles aligned with research questions and the scope of the inquiry. Through this process, a breadth of information was garnered from inclusion of literature that employed different methodologies. Among the methodologies present within the literature were mixed methods study, experimental single-subject design, quantitative research, experimental study with statistical analysis, cross-linguistic interdisciplinary research study, multiple baseline and multiple probes across subjects with a single-case design, and systematic literature reviews. The collection of our data involved the application of several strategies, including the evaluation and synthesis of personal research findings; undertaking evaluation and analysis of primary channels, like the revision of several journals; examination of reference lists of other articles; and the examination of secondary channels, bibliographies, and reference databases. This process was conducive to critically answering the study questions: How are multi-sensory phonics programs beneficial to student learning? How could multi-sensory phonics programs impact teaching English as an additional language? How can teacher training in multi-sensory phonics programs support teacher efficacy?

The analysis of the articles presented in this section has been foundational in the attempt to answer the study inquiries. In regards to the benefits of MSPPs, findings indicate that their implementation, within a balanced reading approach, provides students with additional supports — visual, auditory, kinesthetic, and tactile — as they build PA and phonics skills (Schneider \& Kulmhofer, 2016) in a systematic and sequential approach that is known to have the highest impact in reading instruction (NICHD, 2000). 
Specifically, these programs offer consistent benefits in reading and overall literacy skills, as pointed out in multiple studies. Consequently, MSPPs not only offer those same benefits to ELL instruction while supporting different learning styles and learning needs, but as FFI, they also draw students' attention to linguistic features that support recognition of language forms that may not be evident for language learners. As such, the implementation of MSPPs in TEAL settings seems to be a strong pedagogical tool that works at its best when teachers are provided with proper training (Asip, 2012; Carey, 2016).

To determine whether multi-sensory input and structured language instruction promoted better letter name recognition, letter sound production, and word decoding and encoding, Schlesinger and Gray (2017) utilized a multiple-baseline, multiple-probe single-case design method with an embedded treatment design to evaluate the efficacy of the multi-sensory program. Participants of the study included 11 Grade 2 students, with some students exhibiting expected development and others with learning challenges. Even though multi-sensory input did not provide a higher effect when compared to structured language in that study, a potential cause of this was how little time was invested on engaging and practising strategies and the overall duration of the treatment phase. As an OG-based program, the study showed that MSPPs comprise an effective structured language instruction program. These findings align with literature that supports systematic instruction for developing foundational decoding and encoding skills, validating the impact MSPPs have on learning.

A quantitative research study by Carey (2016) analyzed elementary teachers' use of multi-sensory instruction. Of the 208 elementary teachers who were surveyed, including an analysis of teacher training in correlation with multi-sensory training, those with greater multi-sensory experience had higher levels of self-efficacy of linguistic knowledge factor (SELF). Adversely, the author found that no correlation was found between self-efficacy of reading factor (SERF) and multi-sensory training. It is asserted that SELF, subcomponents of PA, and phonics instruction require greater knowledge and understanding of linguistic concepts. As such, PA and phonics skills, represented within SELF, may be necessary for readers to become more accurate and automatic decoders. Despite the low sample size and lack of generalization across other learning contexts within the study, there is enough evidence to suggest that MSPPs impact student reading.

A cross-linguistic and interdisciplinary research study by Schneider and Kulmhofer (2016) sought to identify language transferability through the integration of 
multi-sensory structured language (MSL) approaches in foreign and second-language instruction (FSL). The study supports a balanced approach to FSL instruction with the integration of MSL. In doing so, struggling learners had a chance to succeed in English as an additional language. However, it was recommended that research on the impact of MSL learning in FSL be considered. Schneider and Kulmhofer (2016) concluded that MSPPs have the potential to impact teaching English as an additional language.

Warnick and Caldarella (2016) conducted an experimental study over eight weeks using multi-sensory-based instruction. The treatment group showed higher gains in reading scores than the control group. Results suggested reading difficulties in adolescent delinquents can be effectively remediated using a multi-sensory phonics program. Furthermore, the results of the current study revealed that significant gains can be achieved with 30 hours of multi-sensory phonics instruction, which is consistent with more recent research on phonics intervention (Warnick \& Caldarella, 2016, p. 328). This reflects the ongoing thesis within this research inquiry and integrative review that MSPPs improve student achievement. Within the Warnick and Caldarella (2016) study, the benefits of MSPI are more apparent despite the small sample size and the need for replication.

In Asip's (2012) work, a formative evaluation of a multi-sensory reading program was conducted. This mixed-method study utilized quantitative and qualitative data analysis and correlational statistical methods to determine the relationship between multi-sensory instruction received by students, as well as their overall gain in reading achievement. According to the study, no correlation was evident between the allocated hours of multi-sensory instruction and overall gain scores demonstrated by participants within the study, aligning with our research question of whether MSPPs impact student learning. Asip's (2012) findings assert that strengthening multi-sensory phonics program implementation may produce more desirable outcomes.

An experimental single subject design study by Campbell et al. (2008) analyzed the effectiveness of multi-sensory instruction in reading. Data collected during twenty lessons, along with information collected from intervention checklists, measured the integrity of an explicit supplemental multi-sensory reading program. The limitations of the study were confined to the generality of the results, reflective in the small sample size and the continuation of additional study replications. Moreover, teachers with experience in MSPPs, inclusive of additional instructional support, may have skewed some of the results. Notwithstanding that, Campbell et al. (2008) assert that when multi-sensory 
components are added as part of a reading program or initiative, the additional support contributes to student improvement in reading accuracy and fluency. These results illustrate the impact of MSPPs on students' learning and achievement.

Scheffel at al. (2008) examined the effectiveness of a multi-sensory Orton-Gillingham reading program as a supplement to regular Grade 1 classroom instruction. Participants included Grade 1 students from three schools, with 227 students constituting the treatment group and 535 students the comparison group. Methodologies used were broad in their scope and included pre-and post-tests, classroom observations, and teacher surveys. Scheffel at al. (2008) postulated that, on average, adopting and delivering the program led to higher teacher satisfaction. Data from the study shows that teachers who experienced a form of MSPI in their teaching showed significantly more interest in continuing to implement the program in their classrooms. Scheffel at al. (2008) concluded that MSPPs lead to accelerated and more effective acquisition of student proficiency in PA and alphabetic principle skills in Grade 1 students, supporting the theory that MSPPs impact student learning and achievement.

Turner's (2008) systematic and empirical assessment review of the literature explores the effectiveness of the Orton-Gillingham-based reading instruction program. In 12 quasi-experimental studies and one experimental study, evidence suggests that after reading interventions based on the principles of OG instruction were delivered, five groups outperformed on all outcomes, four groups outperformed on at least one outcome, two underperformed after treatment, and one reported no difference. The treatment group outperformed the control group on spelling. Overall, student achievement through multi-sensory phonics instruction (MSPI) contributed to improvement by meeting language outcomes, a significant benefit of implementing MSPPs within the classroom. However, Turner (2008) advanced that a limitation of OG-based reading instruction is that it is premature to draw conclusions on overall effectiveness due to the lack of comparability of groups in quasi-experimental studies.

Joshi et al. (2002) completed a one-year multi-sensory method of instruction and language study for Grade 1 students. In the study, 24 participants comprised the treatment group and 32 the control group. This experimental study utilized statistical analysis to measure the treatment and control groups on reading skills. The evaluation strategy included testing on PA, a word attack subtest of the Woodcock Reading Mastery Rest, and the comprehension section of the Gates-MacGinitie Reading Test. Notably, children 
in the treatment group scored significantly higher than the control group on phonological awareness, decoding, and comprehension, which suggests that multi-sensory training can improve spelling achievement. Furthermore, as an example of systematic research-based reading instruction, this is crucial for reading development at the early elementary grade levels. While the study did not demonstrate that MSPPs impact student learning, further research on whether teacher training on MSPPs impact program efficacy would be valuable. Moreover, additional investigation on the effect of multi-sensory approaches in other grades would be important to consider.

Oakland et al. (1998) completed a two-year application of the Dyslexia Training Program, an Orton-Gillingham-derived and multi-sensory phonics instructional method, to assess students with a diagnosis of dyslexia on their reading comprehension, word recognition, and spelling. Subtests on monosyllabic and polysyllabic phonological transfer to measure decoding skills were also administered. The study demonstrated that students who were taught by teachers trained in the OG-derived method saw their students make significant gains in overall ability to decode nonsense words, word recognition, and reading comprehension. This study was able to establish a correlation between MSPPs and student achievement and development.

A summary of each of these studies is provided in the Appendix.

\section{Synthesis}

When evaluating the data garnered from the articles used for this integrative review, patterns and themes emerged. These patterns and theme were central in identifying the need for phonics instruction as it is held that implementation of MSPPs works as a reading support with an FFI approach. An earlier study (Wikerson et al., 2012) referenced by Warnick and Caldarella (2016) noted that, beyond the emphasis remediation programs have on comprehension and vocabulary, struggling readers may most likely require phonics development (p. 318) to master phonemic principles, which are fundamental for reading proficiency. Along those lines, this review demonstrated that by incorporating MSPPs, students of varying age ranges could improve reading performance and oral reading fluency (Campbell et al., 2008); improve phonemic awareness, decoding, and comprehension skills (e.g., Joshi et al., 2002); meet language outcomes; and improve spelling (Turner, 2008) and decoding and encoding skills (Schlesinger \& Gray, 2017). 
Research by Warnick and Caldarella (2016) evaluated the impact of MSPPs in adolescents with reading difficulties. They emphasized the need for additional studies to connect MSPPs with other teaching contexts, as few studies may have been performed in relation to them (p. 331). Further, Asip (2012) attempted to provide evidence on the effects of MSPPs in regular class settings at a district level. However, it was their belief that future research would be desirable in other school jurisdictions and programs. Carey (2016) also argued for the need to study replicas in other regions and countries. Consequently, Schneider and Kulmhofer's (2016) appeal for research on multi-sensory phonics programs in connection with English language learning is supported by previous research. It was also asserted that additional research be conducted to address the gap in the literature between MSPPs and L2 instruction. However, the premise that MSPPs, overall, impact student learning among students with diverse needs and challenges and those without (Warnick and Caldarella, 2016, p. 328) could be an indicator of the transferability of MSPPs to English language learning contexts.

Data emerging from the analysis conducted by Warnick and Caldarella (2016) suggested the continued need for teacher professional development to bolster the benefits from MSPPs implementation. As Carey (2016) explored the association between teacher training in multi-sensory reading and self-efficacy of linguistic knowledge factor, it was suggested that teacher training in MSPPs increases teacher linguistic knowledge, which is necessary in teaching students to read (p. 35). Correspondingly, other articles, including Scheffel et al. (2008), manifested teacher engagement and satisfaction with MSPPs, while others (Warnick \& Caldarella, 2016) pointed to the low-cost and ease of MSPPs implementation. Whereas some researchers, like Asip (2012), found no major correlation between multi-sensory instruction and gain scores, it was believed that study results were influenced by inconsistent program implementation, as a new initiative, and/or teacher lack of training in the use of the MSPP.

\section{Discussion}

A synthesis of the literature has led to findings showing how proper implementation of MSPPs can be a strong component of a balanced reading program (Asip, 2012) that provides L1 and L2 learners with visual, auditory, kinesthetic, and tactile supports 
(Schneider \& Kulmhofer, 2016) to connect "sounds, syllables, words, sentences, and written discourse...[within] explicit, systematic, cumulative, direct, and sequential [instruction]" (Joshi et al., 2002, p. 231). Furthermore, multi-sensory phonics programs focusing on PA and phonics instruction can impact vocabulary, fluency, and reading comprehension. These are all factors known to be foundational in reading development (NICHD, 2000) and supported throughout this study. Moreover, by incorporating differentiation techniques and diverse learning styles, MSPPs can provide L1 and L2 students with reading support, of particular benefit to struggling learners and the increasingly diverse ELL population. Thus, elementary teachers, specialists, consultants, schools, and school districts across Canada may find MSPPs valuable as an important element in a balanced literacy program, particularly in elementary classrooms, but inclusive of middle school and high school ELLs with reading difficulties, as attested by Warnick and Caldarella (2016).

The integrative review on the Impact of Multi-Sensory Phonics Programs in Teaching English as an Additional Language serves to identify strengths of MSPPs in reading instruction within regular school settings (Asip, 2012; Carey, 2016; Joshi et al., 2002; Scheffel et al., 2008; Warnick \& Caldarella, 2016), as supplemental education (Campbell et al., 2008), remediation programs for students with learning difficulties (Oakland et al., 1998), and for both students with typical development and those with learning challenges (Schlesinger \& Gray, 2017). The impact of MSPPs on student learning has been evidenced across age groups and grades, from elementary and up to 18-yearold adolescents (Warnick \& Caldarella, 2016). These assertions and recent cross-linguistic and interdisciplinary research in relation to ELLs by Schneider and Kulmhofer (2016), contribute to answering the second study question regarding how MSPPs may impact TEAL. The differing learning contexts and student demographics gathered in this study suggest that benefits from the implementation of MSPPs are transferable to various learning contexts, grades, and ages, which makes us believe that MSPPs not only impact English language learners' multiple reading skills but that they could, in addition, improve their pronunciation, listening, writing (Schneider \& Kulmhofer, 2016), and spelling (Joshi et al., 2002).

Although it is logical to assert that program implementation success may depend on training, the analysis drawn from this review signals how success in the implementation of MSPPs is highly dependent on proper teacher training and follow-up (Asip, 2012, 
pp. 131-132). Equivalently, Carey (2016) links multi-sensory instruction training and teacher linguistic knowledge, and recommends that teacher education programs provide multi-sensory and linguistic training as part of their certification and other modalities for in-service and new graduate teachers (pp. 83-84). It is thought that teacher training may result in enhanced MSPP implementation that could provide a stronger foundation for reading skills development. For bilingual or multilingual teachers, additional training may be required to strengthen their linguistic language knowledge. As well, native English-speaking teachers, having learned the language without major attention to the forms, may need more language awareness and development training.

Lastly, in light of early stages of reading development being foundational to subsequent school years where students shift from learning to read to reading to learn and progress "from learning about the correspondence between letters and sounds to reading for comprehension and accessing information"(Pavlov, 2015, p. 31), this study may not only be of interest to kindergarten to Grade 3 teachers, but may also serve those who teach middle school and high school ELLs who struggle with reading due to disabilities or learning gaps (Warnick \& Caldarella, 2016).

\section{Limitations}

Despite the focal points discussed, limitations within the study and the articles analyzed have been observed. As to the scrutinized studies, most were from a single country, the United States, and only two out of 10 were developed in an English language learning context. One limitation within the spectrum of the review was the inclusion of studies conducted only in English that were translated to English, or included English language learning in connection to MSPPs but did not include studies that attested to the effectiveness of MSPPs in learning a language other than English as a L1 or L2. Additionally, this literature review is represented by the inclusion of non-peer-review articles (Asip, 2012; Carey, 2016; Schneider \& Kulmhofer, 2016) due to the lack of peer-review studies found during the literature search stage.

Amongst all the underscored benefits of MSPPs found in this study, as many of the articles reviewed were examining a single grade, or school division, warnings that findings do not allow for generalizations to other grades (including older grades) and/or 
divisions, were noted. Similar is the case of a few studies with small sample sizes, creating the need for additional study replications, inclusive of replications in other sectors of the cities and countries. In some cases, the implementation of MSPPs was a new initiative. This resulted in a lack of consistent implementation and follow-up with some teachers who expressed their lack of familiarity with the program, leading to the assumption that some study outcomes could have been impacted. Two final limitations included the lack of comparability groups in quasi-experimental studies and the possibility of bias within studies when intervention and testing were performed by the study author.

\section{Conclusion and Future Studies}

Our integrative review provides documented evidence arguing student learning is impacted by the implementation of MSPPs. The benefits of these approaches are evident across learning contexts with student achievement, regardless of learning needs, strengths, challenges, or whether delivery of MSPPs occurred in L1 or L2 instruction. Data collected demonstrates that the implementation of MSPPs provides systematic PA and phonics instruction while improving the other fundamentals of reading, vocabulary, fluency, and reading comprehension. As a result, these programs, as an FFI approach, offer valuable support in L2 acquisition. Simultaneously, these programs afford opportunities for the use of multiple learning modes that result in engaging learning experiences of particular benefit to struggling English native speakers and ELLs.

Admitting that the evidence collected has also pointed to the need for further research into the impact of MSPPs in English as an additional language context, Schneider and Kulmhofer's (2016) research attests that MSPP implementation within a balanced language learning approach can, realistically, help all language learners, even struggling ones, have more probabilities to succeed. Further, even though only one study (Warnick \& Caldarella, 2016) was performed with older students, findings propose that MSPPs can be of support to older struggling readers, which could include beginner ELLs in middle and high school grades.

Findings have led us to believe that the greater the investment in implementing MSPPs as a reading approach, together with professional development on multi-sensory phonics instruction, the greater the impact on program implementation and student 
reading skills. Future studies could encompass experimental research with larger sample sizes and students of different grades, schools, and demographics, inclusive of TEAL classrooms. Finally, even though the literature review provided valuable data on MSPPs, it was not possible to garner significant information on the specifics of the programs applied, besides the Orton-Gillingham program. As a result, it is recommended that future research be done to identify multi-sensory phonics programs that are the most effective in accordance with the learning audiences. 


\section{Appendix 1}

\section{Summary of Studies}

\begin{tabular}{|c|c|c|c|c|c|c|}
\hline $\begin{array}{c}\text { Author } \\
\text { Year } \\
\text { Country of } \\
\text { Study }\end{array}$ & $\begin{array}{l}\text { Intervention/ } \\
\text { Innovation }\end{array}$ & Sample & Method & $\begin{array}{l}\text { Evaluation } \\
\text { Strategy }\end{array}$ & $\begin{array}{c}\text { Results and } \\
\text { Significance of the } \\
\text { Study }\end{array}$ & $\begin{array}{l}\text { Limitations/ } \\
\text { Suggestions }\end{array}$ \\
\hline $\begin{array}{l}\text { Schlesinger \& } \\
\text { Gray } \\
2017 \\
\text { USA }\end{array}$ & $\begin{array}{l}\text { Promoting better } \\
\text { letter name, } \\
\text { letter sound } \\
\text { production, word } \\
\text { decoding, and } \\
\text { encoding through } \\
\text { multi-sensory } \\
\text { input and struc- } \\
\text { tured language } \\
\text { instruction. }\end{array}$ & $\begin{array}{l}11 \text { Grade } 2 \text { stu- } \\
\text { dents ranged in } \\
\text { age from seven } \\
\text { years and eight } \\
\text { months to eight } \\
\text { years and eight } \\
\text { months with ex- } \\
\text { pected develop- } \\
\text { ment and those } \\
\text { with challenges. }\end{array}$ & $\begin{array}{l}\text { A multiple } \\
\text { baseline, } \\
\text { multiple probes } \\
\text { across subjects } \\
\text { single-case } \\
\text { design, with an } \\
\text { embedded treat- } \\
\text { ment design to } \\
\text { compare the } \\
\text { efficacy of the } \\
\text { multi-sensory } \\
\text { program. }\end{array}$ & $\begin{array}{l}\text { Assessments } \\
\text { administered } \\
\text { during each } \\
\text { phase of the } \\
\text { study; graphed } \\
\text { data was visual- } \\
\text { ly analyzed and } \\
\text { weighted with } \\
\text { a non-overlap } \\
\text { index of effect. }\end{array}$ & $\begin{array}{l}\text { Effective structured } \\
\text { language instruction } \\
\text { within an Orton-Gill- } \\
\text { ingham-based program. } \\
\text { Multi-sensory input did } \\
\text { not provide a treatment } \\
\text { effect above and beyond } \\
\text { the structured language } \\
\text { effect. Study supported } \\
\text { extant literature that } \\
\text { explicit systematic } \\
\text { language instruction is } \\
\text { important for developing } \\
\text { foundational decoding } \\
\text { and encoding skills. }\end{array}$ & $\begin{array}{l}\text { Reading and spelling } \\
\text { practices not commonly } \\
\text { utilized in classrooms. } \\
\text { Practice with strategies } \\
\text { prior to the study could } \\
\text { help control new learning } \\
\text { techniques and strategies } \\
\text { and influence on outcomes. } \\
\text { Poor response by partic- } \\
\text { ipants with dyslexia to } \\
\text { either intervention may } \\
\text { have been due to the short } \\
\text { duration of the treatment } \\
\text { phase. }\end{array}$ \\
\hline
\end{tabular}




\begin{tabular}{|c|c|c|c|c|c|c|}
\hline $\begin{array}{l}\text { Author } \\
\text { Year } \\
\text { Country of } \\
\text { Study } \\
\end{array}$ & $\begin{array}{l}\text { Intervention/ } \\
\text { Innovation }\end{array}$ & Sample & Method & $\begin{array}{c}\text { Evaluation } \\
\text { Strategy }\end{array}$ & $\begin{array}{l}\text { Results and } \\
\text { Significance of the } \\
\text { Study }\end{array}$ & $\begin{array}{l}\text { Limitations/ } \\
\text { Suggestions }\end{array}$ \\
\hline $\begin{array}{l}\text { Carey et al. } \\
2016 \\
\text { USA }\end{array}$ & $\begin{array}{l}\text { Examination of } \\
\text { elementary teach- } \\
\text { ers in multi-sen- } \\
\text { sory instruction. }\end{array}$ & $\begin{array}{l}208 \text { elementary } \\
\text { school teachers. }\end{array}$ & $\begin{array}{l}\text { Quantitative re- } \\
\text { search through } \\
\text { use of surveys. }\end{array}$ & $\begin{array}{l}\text { Survey analyzes } \\
\text { teacher training } \\
\text { in correlation } \\
\text { with multi-sen- } \\
\text { sory training. } \\
\text { Literature anal- } \\
\text { ysis of the gap } \\
\text { on multi-sensory } \\
\text { training and } \\
\text { self-efficacy to } \\
\text { teach reading. }\end{array}$ & $\begin{array}{l}\text { Elementary teachers } \\
\text { with greater multi-senso- } \\
\text { ry experience had higher } \\
\text { levels of self-efficacy of } \\
\text { linguistic factor (SELF). } \\
\text { There was no correlation } \\
\text { between self-efficacy of } \\
\text { reading factor (SERF) } \\
\text { and multi-sensory train- } \\
\text { ing. }\end{array}$ & $\begin{array}{l}\text { Due to sample size, study } \\
\text { results cannot be gener- } \\
\text { alized to other states or } \\
\text { countries. }\end{array}$ \\
\hline $\begin{array}{l}\text { Schneider \& } \\
\text { Kulmhofer } \\
2016 \\
\text { Brazil }\end{array}$ & $\begin{array}{l}\text { Integration of } \\
\text { Multi-senso- } \\
\text { ry Structured } \\
\text { Language (MSL) } \\
\text { approach in } \\
\text { Foreign/second } \\
\text { language (FSL) } \\
\text { instruction. }\end{array}$ & & $\begin{array}{l}\text { Cross-linguistic } \\
\text { and interdisci- } \\
\text { plinary research } \\
\text { to identify } \\
\text { language trans- } \\
\text { ferability. }\end{array}$ & & $\begin{array}{l}\text { Study supports a bal- } \\
\text { anced approach to FSL } \\
\text { instruction with inte- } \\
\text { gration of MSL to help } \\
\text { struggling learners have } \\
\text { a chance to succeed in a } \\
\text { foreign/second language, } \\
\text { like English. }\end{array}$ & $\begin{array}{l}\text { Additional research to be } \\
\text { conducted in languages } \\
\text { other than English and in } \\
\text { different FSL learning con- } \\
\text { texts. Additional research } \\
\text { to explore the impact of } \\
\text { multimedia MSL learning } \\
\text { in FSL. }\end{array}$ \\
\hline $\begin{array}{l}\text { Warnick \& } \\
\text { Caldarella } \\
\text { 2016 } \\
\text { USA }\end{array}$ & $\begin{array}{l}\text { Multi-sensory } \\
\text { phonics-based } \\
\text { program to re- } \\
\text { mediate reading } \\
\text { difficulties in } \\
\text { poor readers. }\end{array}$ & $\begin{array}{l}20 \text { juvenile } \\
\text { delinquents ( } 10 \\
\text { control in group, } \\
10 \text { in treatment } \\
\text { group) who were } \\
\text { poor readers. }\end{array}$ & $\begin{array}{l}\text { Experimental } \\
\text { study with } \\
\text { pretest-posttest } \\
\text { and WJTA } \\
\text { reading subtest } \\
\text { for qualifying } \\
\text { participants. }\end{array}$ & $\begin{array}{l}30 \text { hours of } \\
\text { multi-sen- } \\
\text { sory-based } \\
\text { instruction over } \\
\text { an eight-week } \\
\text { period. }\end{array}$ & $\begin{array}{l}\text { Treatment group showed } \\
\text { higher gains in reading } \\
\text { scores than the control } \\
\text { group. } \\
\text { Spelling and Reading } \\
\text { with Riggs MSPP offers } \\
\text { low-cost, easy imple- } \\
\text { mentation, and immedi- } \\
\text { ate student feedback. } \\
\text { Supports all learners. }\end{array}$ & $\begin{array}{l}\text { Small sample size in- } \\
\text { tervention and need for } \\
\text { replication before definite } \\
\text { conclusions can be made. } \\
\text { Possible testing bias as in- } \\
\text { tervention and testing were } \\
\text { performed by the study } \\
\text { author. Assessments did not } \\
\text { include authentic texts. }\end{array}$ \\
\hline
\end{tabular}




\begin{tabular}{|c|c|c|c|c|c|c|}
\hline $\begin{array}{l}\text { Author } \\
\text { Year } \\
\text { Country of } \\
\text { Study } \\
\end{array}$ & $\begin{array}{l}\text { Intervention/ } \\
\text { Innovation }\end{array}$ & Sample & Method & $\begin{array}{c}\text { Evaluation } \\
\text { Strategy }\end{array}$ & $\begin{array}{l}\text { Results and } \\
\text { Significance of the } \\
\text { Study }\end{array}$ & $\begin{array}{l}\text { Limitations/ } \\
\text { Suggestions }\end{array}$ \\
\hline $\begin{array}{l}\text { Asip } \\
2012 \\
\text { USA }\end{array}$ & $\begin{array}{l}\text { Formative pro- } \\
\text { gram evaluation } \\
\text { of a school dis- } \\
\text { trict's multi-sen- } \\
\text { sory reading } \\
\text { initiative. }\end{array}$ & $\begin{array}{l}422 \text { student par- } \\
\text { ticipants used for } \\
\text { descriptive and } \\
\text { correlation statis- } \\
\text { tical analysis. }\end{array}$ & $\begin{array}{l}\text { Mixed meth- } \\
\text { ods study with } \\
\text { semi-structured } \\
\text { interviews, } \\
\text { online surveys, } \\
\text { focus groups, } \\
\text { document } \\
\text { review, and } \\
\text { analysis of data. }\end{array}$ & $\begin{array}{l}\text { Quantitative } \\
\text { and qualitative } \\
\text { data analysis; } \\
\text { correlational sta- } \\
\text { tistical methods } \\
\text { determined rela- } \\
\text { tionship between } \\
\text { multi-sensory } \\
\text { instruction stu- } \\
\text { dents received } \\
\text { and gain in } \\
\text { reading achieve- } \\
\text { ment. }\end{array}$ & $\begin{array}{l}\text { Correlation between } \\
\text { hours of multi-sensory } \\
\text { instruction and gain } \\
\text { scores showed no signifi- } \\
\text { cant relationship. } \\
\text { Evidence of students } \\
\text { learning reading strate- } \\
\text { gies and increasing their } \\
\text { confidence in reading. } \\
\text { Recommended to } \\
\text { strengthen the imple- } \\
\text { mentation of multi-sen- } \\
\text { sory reading instruction. }\end{array}$ & $\begin{array}{l}\text { Program was not consis- } \\
\text { tently implemented as it } \\
\text { was a new initiative; study } \\
\text { is limited to divisions used; } \\
\text { quantitative and qualitative } \\
\text { data may be useful; there is } \\
\text { no claim of generalization } \\
\text { of findings to other school } \\
\text { divisions or programs. }\end{array}$ \\
\hline $\begin{array}{l}\text { Campbell et al. } \\
2008 \\
\text { USA }\end{array}$ & $\begin{array}{l}20 \text { lessons of an } \\
\text { explicit system- } \\
\text { atic supplemental } \\
\text { multi-sensory } \\
\text { reading program. }\end{array}$ & $\begin{array}{l}\text { Six Grade } 2 \\
\text { students identi- } \\
\text { fied as treatment } \\
\text { resistors. }\end{array}$ & $\begin{array}{l}\text { Experimental } \\
\text { single sub- } \\
\text { ject design to } \\
\text { analyze the } \\
\text { effectiveness of } \\
\text { multi-sensory } \\
\text { instruction on } \\
\text { reading. }\end{array}$ & $\begin{array}{l}\text { Data collected } \\
\text { during testing } \\
\text { and intervention } \\
\text { with checklists } \\
\text { to measure the } \\
\text { integrity of } \\
\text { treatment. }\end{array}$ & $\begin{array}{l}\text { Adding multi-sensory } \\
\text { components to reading } \\
\text { assists students in im- } \\
\text { proving reading accuracy } \\
\text { and oral reading fluency. }\end{array}$ & $\begin{array}{l}\text { Limited generality of the } \\
\text { results due to small sample } \\
\text { size and need of additional } \\
\text { study replications; variation } \\
\text { in teaching expertise and } \\
\text { instructional support may } \\
\text { have impacted results. }\end{array}$ \\
\hline
\end{tabular}




\begin{tabular}{|c|c|c|c|c|c|c|}
\hline $\begin{array}{c}\text { Author } \\
\text { Year } \\
\text { Country of } \\
\text { Study } \\
\end{array}$ & $\begin{array}{l}\text { Intervention/ } \\
\text { Innovation }\end{array}$ & Sample & Method & $\begin{array}{l}\text { Evaluation } \\
\text { Strategy }\end{array}$ & $\begin{array}{c}\text { Results and } \\
\text { Significance of the } \\
\text { Study }\end{array}$ & $\begin{array}{l}\text { Limitations/ } \\
\text { Suggestions }\end{array}$ \\
\hline $\begin{array}{l}\text { Scheffel et al. } \\
2008 \\
\text { USA }\end{array}$ & $\begin{array}{l}\text { Examined the } \\
\text { effectiveness of } \\
\text { multi-sensory Or- } \\
\text { ton-Gillingham } \\
\text { reading program } \\
\text { as a supplement } \\
\text { to regular Grade } \\
1 \text { classroom } \\
\text { instruction. }\end{array}$ & $\begin{array}{l}\text { Grade } 1 \text { stu- } \\
\text { dents from three } \\
\text { schools: } 227 \\
\text { students in the } \\
\text { treatment group } \\
\text { and } 535 \text { students } \\
\text { in the compari- } \\
\text { son group. }\end{array}$ & $\begin{array}{l}\text { Experimental } \\
\text { study with } \\
\text { treatment and } \\
\text { control groups. }\end{array}$ & $\begin{array}{l}\text { Pre- and } \\
\text { post-tests for } \\
\text { treatment and } \\
\text { control groups; } \\
\text { classroom obser- } \\
\text { vations; teacher } \\
\text { surveys. }\end{array}$ & $\begin{array}{l}\text { High teacher satisfaction } \\
\text { with the program. } \\
\text { Supplemental reading } \\
\text { program helped acquire } \\
\text { phonemic awareness } \\
\text { and alphabetic principle } \\
\text { skills. }\end{array}$ & $\begin{array}{l}\text { Analysis of longitudinal } \\
\text { data for treatment students } \\
\text { could determine if Grade } 1 \\
\text { intervention leads to signif- } \\
\text { icant progress in Grade } 2 \text {. } \\
\text { Insufficient data to explain } \\
\text { high proficiency in alpha- } \\
\text { betic principle by Hispanic } \\
\text { females; further investiga- } \\
\text { tions may help determine if } \\
\text { reading programs are espe- } \\
\text { cially beneficial to female } \\
\text { Hispanic students. }\end{array}$ \\
\hline $\begin{array}{l}\text { Turner } \\
2008 \\
\text { USA }\end{array}$ & $\begin{array}{l}\text { Effectiveness of } \\
\text { the Orton-Gill- } \\
\text { ingham }(\mathrm{OG}) \\
\text { and OG-based } \\
\text { reading instruc- } \\
\text { tion, using visual, } \\
\text { auditory, and } \\
\text { kinesthetic-tac- } \\
\text { tile learning } \\
\text { modalities. }\end{array}$ & $\begin{array}{l}12 \text { quasi-exper- } \\
\text { imental and one } \\
\text { experimental } \\
\text { study. }\end{array}$ & $\begin{array}{l}\text { Systematic lit- } \\
\text { erature review. }\end{array}$ & $\begin{array}{l}\text { Empirical } \\
\text { assessment of } \\
\text { literature on OG } \\
\text { and OG-based } \\
\text { instruction. }\end{array}$ & $\begin{array}{l}\text { OG instruction showed } \\
\text { that after the interven- } \\
\text { tion, five groups outper- } \\
\text { formed on all outcomes, } \\
\text { four groups outper- } \\
\text { formed on at least one } \\
\text { outcome, two underper- } \\
\text { formed after treatment, } \\
\text { and one reported no } \\
\text { difference. The treatment } \\
\text { outperformed the control } \\
\text { group on spelling. }\end{array}$ & $\begin{array}{l}\text { Scientific knowledge on } \\
\text { OG and OG-based reading } \\
\text { instruction is still immature } \\
\text { to draw conclusions on } \\
\text { effectiveness. } \\
\text { Lack of comparability of } \\
\text { groups in quasi-experimen- } \\
\text { tal studies. }\end{array}$ \\
\hline
\end{tabular}




\begin{tabular}{|c|c|c|c|c|c|c|}
\hline $\begin{array}{l}\text { Author } \\
\text { Year } \\
\text { Country of } \\
\text { Study }\end{array}$ & $\begin{array}{l}\text { Intervention/ } \\
\text { Innovation }\end{array}$ & Sample & Method & $\begin{array}{c}\text { Evaluation } \\
\text { Strategy }\end{array}$ & $\begin{array}{c}\text { Results and } \\
\text { Significance of the } \\
\text { Study }\end{array}$ & $\begin{array}{l}\text { Limitations/ } \\
\text { Suggestions }\end{array}$ \\
\hline $\begin{array}{l}\text { Joshi et al. } \\
2002 \\
\text { USA }\end{array}$ & $\begin{array}{l}\text { One-year } \\
\text { multi-senso- } \\
\text { ry method of } \\
\text { instruction and } \\
\text { language basics. }\end{array}$ & $\begin{array}{l}24 \text { Grade } 1 \text { par- } \\
\text { ticipants made } \\
\text { up a treatment } \\
\text { group and } 32 \\
\text { in the control } \\
\text { group. }\end{array}$ & $\begin{array}{l}\text { Experimental } \\
\text { study with sta- } \\
\text { tistical analysis } \\
\text { to measure the } \\
\text { treatment and } \\
\text { control groups } \\
\text { on reading. }\end{array}$ & $\begin{array}{l}\text { - Test of } \\
\text { Phonological } \\
\text { Awareness } \\
\text { - Word Attack } \\
\text { subtest of Wood- } \\
\text { cock Read- } \\
\text { ing Mastery } \\
\text { Test-Revised } \\
\text { - Comprehen- } \\
\text { sion part of the } \\
\text { Gates-MacGini- } \\
\text { tie Reading Test }\end{array}$ & $\begin{array}{l}\text { Children in the treat- } \\
\text { ment groups scored } \\
\text { significantly higher than } \\
\text { the control group on } \\
\text { phonological awareness, } \\
\text { decoding, and compre- } \\
\text { hension. } \\
\text { Multi-sensory training } \\
\text { could also improve } \\
\text { spelling. }\end{array}$ & $\begin{array}{l}\text { Study included only one } \\
\text { grade level. It would be } \\
\text { beneficial to study the } \\
\text { efficacy of multi-sensory } \\
\text { training approach in other } \\
\text { grades. } \\
\text { Relatively small sample } \\
\text { size of } 24 \text { participants in } \\
\text { the treatment group. }\end{array}$ \\
\hline $\begin{array}{l}\text { Oakland et al. } \\
1998 \\
\text { USA }\end{array}$ & $\begin{array}{l}\text { A two-year } \\
\text { application of } \\
\text { the Dyslexia } \\
\text { Training Program } \\
\text { (DTP), an Or- } \\
\text { ton-Gillingham } \\
\text { (OG) derived } \\
\text { method. }\end{array}$ & $\begin{array}{l}48 \text { students with } \\
\text { dyslexia: } 22 \\
\text { students in the } \\
\text { experimental } \\
\text { group and } 26 \\
\text { in the control } \\
\text { group. }\end{array}$ & $\begin{array}{l}\text { From the exper- } \\
\text { imental group } \\
12 \text { students } \\
\text { received the } \\
\text { video DTP } \\
\text { version, while } \\
\text { the } 10 \text { students } \\
\text { received DTP } \\
\text { teacher directed } \\
\text { instruction. }\end{array}$ & $\begin{array}{l}\text { Students were } \\
\text { tested on reading } \\
\text { comprehension, } \\
\text { word recogni- } \\
\text { tion, and spell- } \\
\text { ing. Subtests on } \\
\text { monosyllabic } \\
\text { and polysyllabic } \\
\text { phonological } \\
\text { transfer mea- } \\
\text { sured decoding } \\
\text { skills. }\end{array}$ & $\begin{array}{l}\text { Students trained in the } \\
\text { OG-derived method } \\
\text { made significant gains } \\
\text { in ability decoding } \\
\text { nonsense words, word } \\
\text { recognition, and reading } \\
\text { comprehension. }\end{array}$ & $\begin{array}{l}\text { Planned subsequent studies } \\
\text { to investigate performance } \\
\text { of language abilities. } \\
\text { Subsequent studies inves- } \\
\text { tigated whether students } \\
\text { demonstrated differences in } \\
\text { reading development. }\end{array}$ \\
\hline
\end{tabular}




\section{References}

Alberta Education. (2009). Kindergarten to grade 12 English as a second language literature review update. https://education.alberta.ca/media/1477345/k-12-eslliterature-review-update-2009.pdf

Asip, M. P. (2012). Program evaluation of a school district's multisensory reading initiative (Paper no. 1539618666) [Doctoral dissertation, College of William \& Mary]. ProQuest Dissertations and Theses. https://dx.doi.org/doi:10.25774/ w4-qy7j-jn23

Campbell, L. M., Helf, S., \& Cooke, N. L. (2008). Effects of adding multisensory components to a supplemental reading program on the decoding skills of treatment resisters (Report). Education \& Treatment of Children, 31(3), 267-295.

Carey, T. A. (2016). Facilitating responsive literacy programs: The relationships between multi-sensory training of elementary teachers and self-efficacy to teach reading (Paper no. 10275089) [Doctoral dissertation, Manhattanville College]. ProQuest Dissertations and Theses.

Ellis, R., Basturkmen, H., \& Loewen, S. (2002). Doing focus-on-form. System (Linköping), 30(4), 419-432. https://doi.org/10.1016/S0346-251X(02)00047-7

Ellis, R. (2015). The importance of focus on form in communicative language teaching. Eurasian Journal of Applied Linguistics, 1(2), 1-12.

Joshi, R., Dahlgren, M., \& Boulware-Gooden, M. (2002). Teaching reading in an inner city school through a multisensory teaching approach. Annals of Dyslexia, 52(1), 229-242. https://doi: 10.1007/s11881-002-0014-9

Kellem, K., \& Halvorsen, A. (2018). Understanding and utilizing form-focused instruction in the language classroom. The ORTESOL Journal, 35, 27-35.

Lai, S., George B., R., Schwanenflugel, P., \& Kuhn, M. (2014). The longitudinal relationship between reading fluency and reading comprehension skills in secondgrade children. Reading \& Writing Quarterly, 30(2), 116-138.

McLaughlin, B. (1992). Myths and misconceptions about second language learning: What every teacher needs to unlearn. National Center for Research on Cultural Diversity and Second Language Learning. 
National Institute of Child Health and Human Development. (2000). Report of the National Reading Panel. Teaching children to read: An evidence-based assessment of the scientific research literature on reading and its implications for reading instruction (NIH Publication No. 00-4769). U.S. Government Printing Office.

Oakland, T., Black, J., Stanford, G., Nussbaum, N., \& Balise, R. (1998). An evaluation of the Dyslexia Training Program: A multisensory method for promoting reading in students with reading disabilities. Journal of Learning Disabilities, 31(2), $140-147$.

Pavlov, V. (2015). Challenges faced by English language learners on the Alberta English Language Arts 30-1 Reading Diploma Examination (Publication no. 10296345) [Doctoral dissertation, University of Calgary]. ProQuest Dissertations \& Theses.

Rasinski, T., Paige, D., Rains, C., Stewart, F., Julovich, B., Prenkert, D., \& Nichols, W. (2017). Effects of intensive fluency instruction on the reading proficiency of third grade struggling readers. Reading \& Writing Quarterly, 33(6), 519-532.

Russell, C. L. (2005). An overview of the integrative research review. Progress in Transplantation, 15(1), 8-13. https://doi.org/10.1177/152692480501500102

Scheffel, D. L., Shaw, J. C., \& Shaw, R. (2008). The efficacy of a supplemental multisensory reading program for first-grade students. Reading Improvement, 45(3), 139-152.

Schlesinger, N., \& Gray, S. (2017). The impact of multisensory instruction on learning letter names and sounds, word reading, and spelling. Annals of Dyslexia, 67(3), $219-258$.

Schneider, E., \& Kulmhofer, A. (2016). Helping struggling learners of English as an additional language succeed with interactive multisensory structured strategies. Brazilian English Language Teaching Journal, 7(1), 3-25.

Snyder, H. (2019). Literature review as a research methodology: An overview and guidelines. Journal of Business Research, 104, 333-339.

Spada, N., \& Lightbown, P. (2010). Second language acquisition. In N. Schmitt (Ed.), Introduction to applied linguistics (pp. 108-124). Hodder Education. 
Stewart, E. D. (2011). The impact of systematic multisensory phonics instructional design on the decoding skills of struggling readers [Doctoral dissertation, Walden University]. ProQuest Dissertations and Theses Global.

Svalberg, A. (2007). Language awareness and language teaching. Language Teaching, 40, 287-308.

Turner, H. M., III. (2008). This systematic review empirically documents that the effectiveness of Orton-Gillingham and Orton-Gillingham-based reading instruction remains to be determined. Evidence-Based Communication Assessment and Intervention, 2(2), 67-69. https://doi.org/10.1080/17489530802037564

Warnick, K., \& Caldarella, P. (2016). Using multisensory phonics to foster reading skills of adolescent delinquents. Reading \& Writing Quarterly, 32(4), 317-335.

Williams, F. (2008). The effects of multisensory phonics and visualization interventions on struggling Readers' word identification, fluency, and comprehension (Publication no. 3340571) [Doctoral dissertation, University of Missouri-St. Louis]. ProQuest Dissertations and Theses. 